\title{
HOUSE DESIGN TRANSFORMATION BY SHORT-TERM OWNERS
}

\author{
Silfia Mona Aryani ${ }^{*}$, Soepono Sasongko ${ }^{1}$, Iik Endang Siti Wahyuningsih ${ }^{1}$ \\ ${ }^{1}$ Department of Interior Design, Faculty of Arts and Designs, Universitas Sebelas Maret, Jl. Ir. Sutami \\ 36A, Kentingan, Surakarta 57126, Indonesia
}

(Received: January 2017 / Revised: May 2017 / Accepted: December 2017)

\begin{abstract}
The initial house provided by the government of Indonesia for low and medium family hence should be in affordable process is called Rumah Inti Tumbuh (RIT). The Indonesian word tumbuh means "to grow", indicating that these houses are expected to be transformed, as a representation of growing, following to the owners' financial improvement and spatial needs. This article is based on the second stage of the research on RIT. The first stage of the research observed units in the Condong Catur Public Housing project in Yogyakarta Province, which was initiated in the 1980s. The findings from the first stage prompted a further research question related to the tendency to transform newer public housing. This article discusses the design transformation of public housing units that have been occupied for shorter periods of time than those units featured in the previous study. The current research employed qualitative methods by observing the occupants of the Wonorejo Public Housing project and the transformations they have made to their homes to meet their expanding spatial needs. The observed units had been occupied for less than five years at the time this research was conducted. Data collection consisted of observing the units, interviewing the occupants, and gaining information from secondary data resources such as the literature and the blue print of the initial design. The observation focused on the development direction and zoning pattern of the units. The research found that the occupants tended to maintain the existing zoning, enlarge semi-public and service spaces, and prioritize development at the back of the housing site. The findings of this second stage research show similar tendencies with the previous research; therefore, these trends could be considered predictive factors that could inform initial RIT design.
\end{abstract}

Keywords: Indonesia; Initial house; Public Housing; RIT; Self-help transformation; Wonorejo

\section{INTRODUCTION}

Design transformation in developing countries is common in housing provided by the government. This transformation might result from initial design being based on crude generalizations, thereby lacking detailed consideration of the occupants' needs in the future (Zavei \& Jusan, 2012). In Indonesia, the initial house provided by the government is known as Rumah Inti Tumbuh (RIT). The Indonesian word tumbuh means "to grow", indicating that these houses are expected to be transformed, as a representation of growing, following to the occupants' financial improvement and spatial needs. Thus, the transformation of these houses seems to be expected by the Indonesian government, allowing it to launch "first housing units" at affordable prices. The definition of RIT gives occupants the right to further development.

\footnotetext{
*Corresponding author's email: Silfia.aryani@staff.uns.ac.id Tel. +62-81327731243, Fax. +62-271-647069 Permalink/DOI: https://doi.org/10.14716/ijtech.v8i6.727
} 
Furthermore, the government offers possibilities for how these houses might be developed in the regulation related to government-provided houses (Menkimpraswil, 2002). This transformation possibility is in line with researchers' findings that occupants will change and adjust their house to satisfy and meet their needs (Manalang et al., 2002; Morris \& Winter, 1975, cited in Rahadi et al., 2012).

Such transformations are, in the majority of cases, due to the occupants' changing spatial needs caused by family growth. According to Handoko (1999), transformation can be in the form of: (a) restoration - minor modifications without changing the structure; (b) remodeling-major modifications without changing the structure; and (c) reconstruction-total modification without maintaining any of the initial structure. The modifications relate to the lay-out or possible room additions, the replacement and/or addition of bedrooms and living rooms, as well as changes to the house's facade (Rahim \& Hashim, 2012). Isnin et al. (2012) state that design transformation can affect both the interior and/or open spaces adjacent to the house and can be made horizontally, vertically, or both.

Occupants need to pay attention to the details of the transformation in order to prevent the inefficient use of resources and avoid material wastage (Kellet, 1993, in Sueca, 2004). Manalang et al. (2002) suggested that at the design stage, the dwelling should be created with consideration for future improvements, and therefore the design should be as flexible as possible. This flexibility creates the potential for the house to incorporate different physical arrangements (Schneider \& Till, 2005a) and meet the changing needs of the user(s) (Schneider $\&$ Till, 2005b). This potential for flexibility can be ensured by generic public housing that is designed based on observations of transformation tendencies and the identification of the parts of the initial design that are maintained after transformation.

This article details the second stage of research on the design transformation of RIT. The previous stage focused on transformations by owners who had occupied their houses in Condong Catur Public Housing since the 1980s. The research (Aryani et al., 2015) concluded that the back of the housing site was the most prioritized location for development, whereas the front and side areas of the properties were also used for further development. Rear development commonly focused for service area, while the front of the house functioned as a public space. Meanwhile, the rest of the house accommodated other spatial requirements. Most of the modifications maintained the placement and dimensions of the private areas of the property. Another result revealed by the research was the tendency of occupants to enlarge the semipublic and service spaces of their properties. The previous study's conclusions prompted a further research question relating to the spatial direction tendency of design transformation involving young families who have occupied their houses since the 2000s; these individuals constitute the research population in this current study. This article discusses expansion directions and zoning transformations in Wonorejo Public Housing units and then compares this new data with the results of the research from Condong Catur Public Housing. The discussion confirms the common trends and characteristics of Indonesian government housing from the 1980s and 2000s. As a result of this research on design transformation, the generic space initially created by the government can be modified sustainably.

\section{METHODOLOGY}

The research was conducted using qualitative methods. The researchers observed three points known as "social situations" (Spradley, 1980 in Sugiyono, 2011). The observation was focused on: (i) the chronology and design transformation of the public housing units as observed activities; (ii) the first owners occupying the unit since the launch of the program until the 
present, as the observed respondents; and (iii) the Wonorejo Public Housing as the observed location.

The data were collected from primary and secondary sources. The primary data came from information collected from the respondents, who were the first owners, and from the unit(s), or artefacts. To collect the data, the researchers chose respondents via purposive sampling; the criteria for selecting the respondents was that they had to be the first owners of the houses. The individuals who first bought these units did not have a design alternative. Therefore, it can be assumed that whatever changes they made were their own adaptations to the existing property. This assumption cannot be applied to second owners, even though they might have bought the unit before it was renovated or altered in any way. The decision to choose first owners as the respondents was also based on the need to collect data regarding any changes to the unit; this data includes reasons for any changes and their chronology. Meanwhile, secondary literature was analyzed for the purpose of comparison.

The researchers collected the data by interviewing the occupants, observing the current condition of the unit, and by documenting the unit's specific features. The data from the respondents was collected through structured interviews because they had knowledge of the desired information. The collection of such owner-specific information was aided by an interview guide that focused the interviews on each unit's design and the chronology of any alterations. The researchers employed a passive participant observation approach to gather information because she needed to remain neutral and therefore did not wish to be involved in the observed activities, for example, as a design advisor in the development process. Observation was confined to units owned by their first buyers in order to identify their modified layouts. The redesign of these houses was documented photographically in particular cases such as the façade changing.

The data were analyzed repeatedly using the model from Miles and Huberman (1984) in (Sugiyono, 2011), which includes data reduction, data display, and conclusions. The first data reduction resulted from sample errors, such as when it was found out a respondent was not the first owner. Data display then represented any design changes and their chronology. Data reduction was then conducted again to eliminate units that had undergone total reconstruction, meaning that the occupant was unable to make adjustments to the initial design. Zoning patterns were then obtained and compared to determine similarities and possible pattern matching; this was the second stage of data display. Once again, data reduction was conducted to omit the least adjustment and facilitate final conclusions.

The data were then tested for credibility by further observation. This testing involved reobserving the housing units and re-interviewing the respondents to confirm the data (Sugiyono, 2011). This process was designed to: (a) check the data collected by the researchers including the house design plan and the unit's actual condition; (b) confirm the explanation of the respondents and document the particular conditions of the units; and (c) complete data collection related to questions that arose during the data analysis such as the profession of the wife as it may influence the transformation.

\section{RESULTS}

Wonorejo Public Housing includes the following three types of houses: type 21/72, type 36/98, and type 45/135. The research focused on type 36/98, which were initially built with two bedrooms, one bathroom, a kitchen, a living room, an area for hosting guests, and a terrace, as well as entrances at the front and back of the house. These units are semi-detached, with shared bedroom walls. They were built with three open spaces - at the back, front, and one side of the house — which could be developed. The observed houses had been occupied since 2013. 

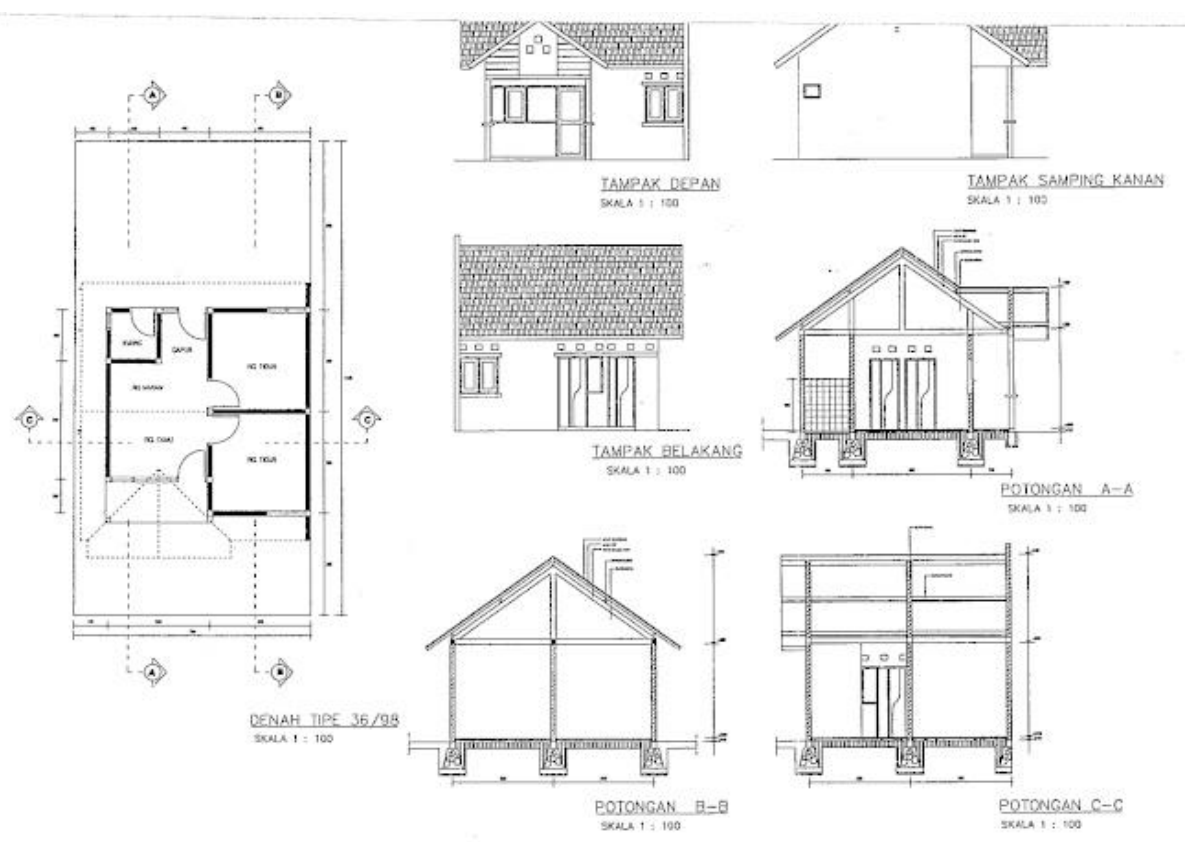

Figure 1 The observed house type 36/98 (Saputra, 2004)

Figure 2 shows the zoning of the 36/98 house. The yellow section represents the public area, which includes a terrace and a space for hosting guests. The blue section represents the semipublic space, i.e., the living room. The red section represents the private space, comprising the two bedrooms, while the green area represents the service area, comprising the bathroom and kitchen.

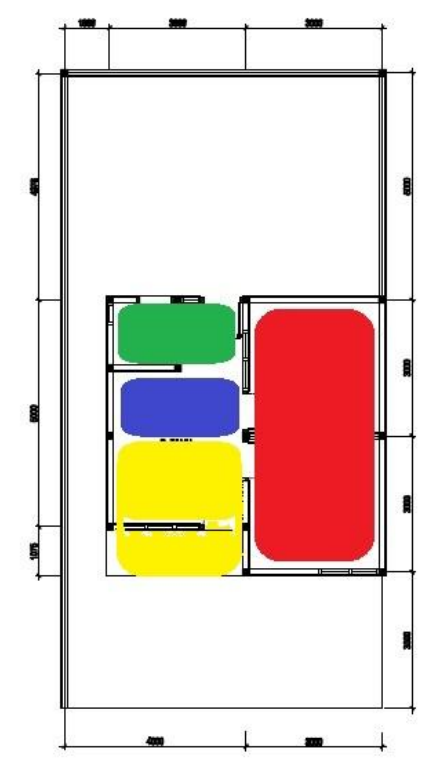

Figure 2 Zoning pattern of initial design for house type 36/98

In the interviews, regarding to the spatial comfort, $83.3 \%$ of owners stated that the houses did not meet their spatial requirements and hence required some development. $16.7 \%$ of the respondents complained about the unit's lack of spatial wideness. Meanwhile regarding to the thermal comfort, $66.7 \%$ occupants are complaining of problematic wall such as fungi 
appearance because of high indoor humidity and $16.7 \%$ occupants feel un-comfort on thermal condition (Aryani et al., 2016).

\subsection{Direction of Extension}

The chronological process may inform the priority level of the expansion. It is scored 0-4. Score 4 represents the most prioritized transformation as it had been done on the earliest stage. Whereas score 0 represents the least prioritized one as it had been done on the last phase or even it is still planned to be expanded. The frequency of the activities may inform the tendency of the expansion, the more frequent expansion occurs represent the most prioritized transformation.

Most of the design transformations used the entire back area of the site (Aryani et al., 2016). Of the 16 observed houses, 15 units (93.75\%) had been extended by optimizing the back area of the house. Back-site extension was indicated as highly prioritized with a score of 3.56 on a scale of 4 . This research found that the second priority area for extension was to the side of the house (with a priority level of 3.38 on a scale of 4), as seen in 14 of the 16 observed houses $(87.5 \%)$. Development at the front of the site was noted in 5 cases out of 16 , or in $31.25 \%$ of houses.

Table 1 Direction of extension

\begin{tabular}{clcc}
\hline No & House Development Activity & $\begin{array}{c}\text { Number of houses } \\
\text { (out of 16) }\end{array}$ & $\begin{array}{c}\text { Priority level } \\
\text { (0-4 scale) }\end{array}$ \\
\hline 1. & Extending into the back area of the site & 15 & 3.56 \\
2. & Extending into the side area of the site & 14 & 3.38 \\
3. & Extending into the front area of the site & 5 & 1.13 \\
4. & Extending the house vertically & 5 & 0.94 \\
\hline
\end{tabular}

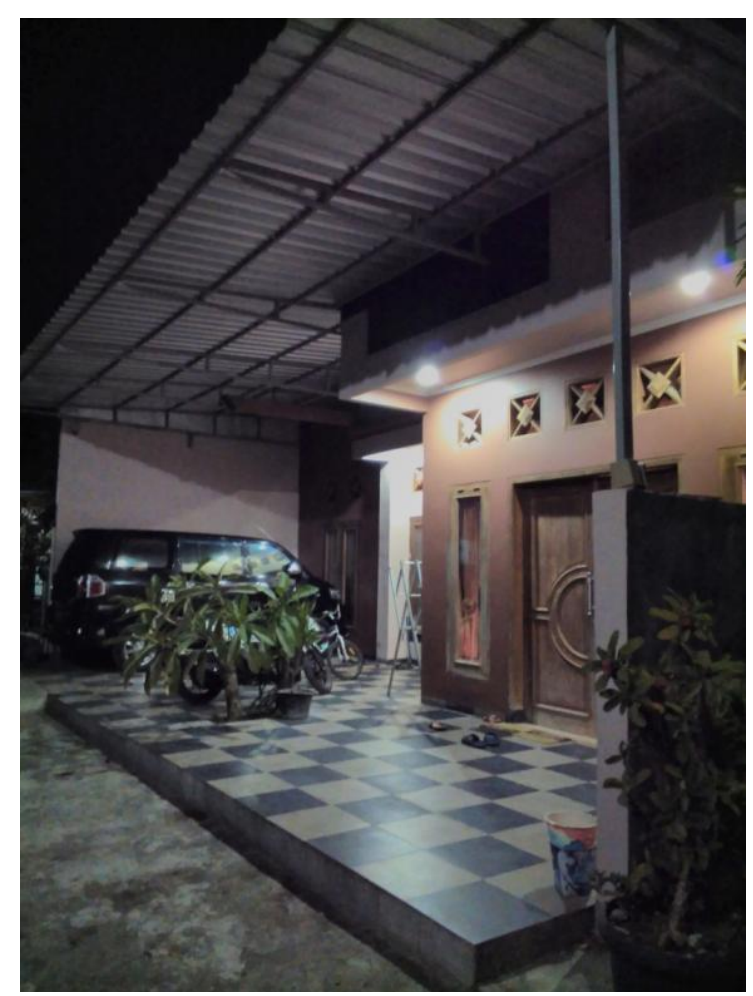

Figure 3 An example of front and side development 


\subsection{Zoning Design Transformation}

The pattern of zone transformation that is mostly implemented occurred in 5 of the 16 observed units (Aryani et al., 2016). The owners maintained the original placement and dimensions of the private area zone. The public zone was extended to the original back wall of the house. The semi-public zone was moved to the middle and side areas and extended to serve as a multipurpose space. The far rear zone functioned as a service area, containing the bathroom and kitchen.

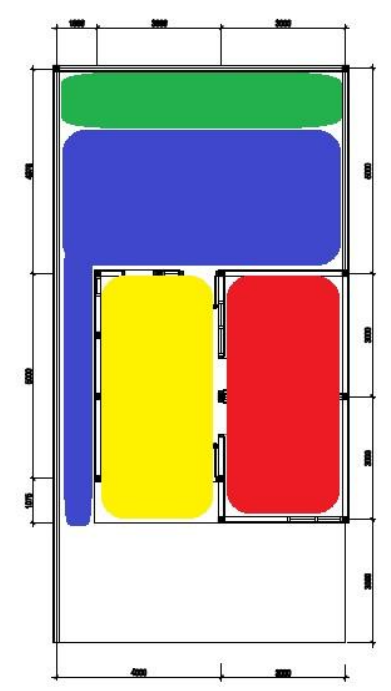

Figure 4 First zoning design transformation

The second most frequently occurring zoning design transformation was found in 4 of the 16 houses. In these cases, the occupants maintained the placement and the dimensions of the public area but altered all other zones. The private area was extended to the rear of the property; a similar modification was made to the semi-public zone. The side of the site was used as a service area for the kitchen, bathroom, and motorcycle garage. The service zone also extended to the front area, generally in order to accommodate a car garage or carport.

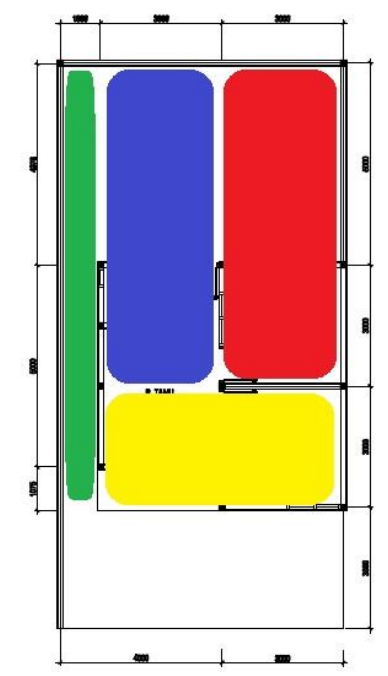

Figure 5 Second zoning design transformation 
The third most frequent zoning design transformation was found in 3 of the 16 observed houses. The occupants maintained the placement and size of both the private and public areas. The semi-public zone was extended to occupy the entire rear of the site, and the side area functioned as a service zone for the kitchen, bathroom, and a motorcycle garage.

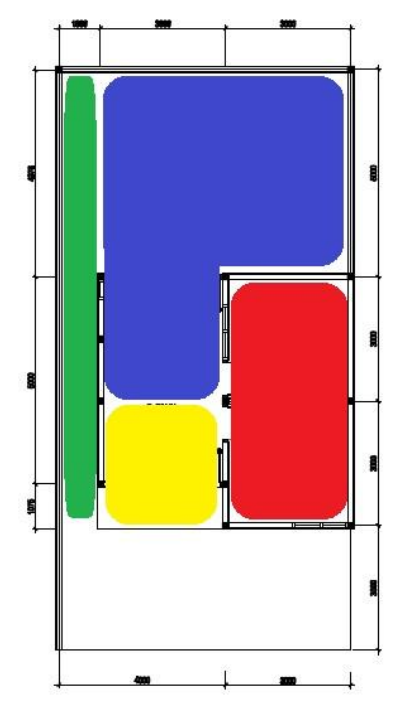

Figure 6 Third zoning design transformation

Of the 16 observed houses, four cannot be placed into any of the three categories of zoning transformation specified above. These all occupied larger sites; therefore, it was possible for the owners to develop their units differently than the owners of the other 12 houses.

\section{DISCUSSION}

\subsection{Direction of Extension}

The current research supports the trend found in previous publications that identified the rear of the site (Natakun \& O'Brien, 2009; Aryani et al., 2015) as the most common area chosen for house expansion. However, this research also identified a significant second priority (87.5\%), where the occupants extended into the side area of the site (scoring a priority level of 3.38 on a scale of 4). This outcome differed from the research of Aryani et al. (2015), which noted the same level of priority given to front and side area development in terms of extension direction. This current study's findings were also contrary to the finding that the front area (Natakun \& O'Brien, 2009; Yatmo \& Atmodiwirjo, 2013) was the most preferred area for house expansion. The tendency to develop the front of the site (only $31.25 \%$ of houses in the present study), presents another difference with the research of Aryani et al. (2015), which found that extension into the front of the site occurred in $92.5 \%$ of their sample.

Prioritization of the side of the site for expansion might result from the size of the space, which can be considered narrow; hence limited extra thought and expenses would be required for expansion into this area. In previous research, vacant side space was quite wide, so the owners might have needed to plan and budget for required funding to expand into this portion of the site. The initiatives in developing the front of the site can be related to the improvement of financial circumstances, which, in turn, create the desire to differentiate one's home from one's neighbors'. Sugini (1999) also noted that modification to a house's facade were made with the owner's intention of personalizing their house. Therefore, the government as the public housing provider should consider the reported preferences for the direction of the extension to give the 
flexibility for the design transformation in the future.

\subsection{Zoning Design Transformation}

A similarity between the current study and previous research was found in the limited interest in vertical expansion, which was the last expansion choice and had a low level of priority (Aryani et al., 2015). Other similarities can be found in terms of zoning transformation, in the tendency to enlarge semi-public areas (Natakun \& O'Brien, 2009) and to maintain the placement and dimensions of the private space (Aryani et al., 2015). The research also suggests the need for planners to anticipate the possible use of spaces for service activities (Yatmo \& Atmodiwirjo, 2013). The service area transformation findings, regarding additions, replacements and enlargement, should also be noted (Natakun \& O'Brien, 2009; Sjaifoel, 2008; Nurasrizal, 2010; Aryani et al., 2015). However, there is a different the preference for kitchen enlargement, which was not as notable as in previous research (Aryani et al., 2015).

This discrepancy in preference for kitchen enlargement between the present and previous research might be the result of socio-cultural differences amongst the owners. In previous research, most of the respondents' wives were housewives who did not work outside the house. They prepared the meal for their family, while gathering and chatting in one of their neighbor's houses. Because they did not work outside of the home, they spent more time in their houses than the other occupants. As such, they evaluated the kitchen more frequently than any other functional space. However, some of the wives of the respondents in the present study did work outside of the home. This may mean they had little time to devote to cooking and hence were very efficient in cooking and dealing with the family's meal preparation that lead to less space need; perhaps, they were also eating out more than previous generations. Even wives who were not working might not have habitually chatted with neighbors while cooking because some of their neighbors were working outside of the home. Therefore, the government as the public housing provider should consider this cultural and contextual differences in order to give the flexibility to tailor the home to meet their individual needs.

\section{CONCLUSION}

Based on the findings of this study and the comparison of these results with those of previous research that focused on longer periods of housing occupation, there are some similarities in terms of the tendency to extend the house by optimizing the rear of the site, as well as the low prioritization given to vertical development.

In terms of zoning, both research initiatives identified similar development tendencies regarding the placement and dimensions of private zones, the location of service areas at the rear of the site, and the extension of semi-public areas. However, respondents who have lived in their homes for a shorter period indicated a different trend toward prioritizing expansion into the side of the site rather than the front, as shown in the previous research. This finding might be influenced by the generic space of the RIT homes; hence, that space can be flexibly developed with minimum destruction and wastage for sustainability purposes.

Therefore, it can be suggested that the Indonesian government as the public housing provider can reduces the need for unit extensions by ensuring new housing units occupy the front part of the site. On initial building, the open space at the side of the house should be wide enough to allow potential development. It should be forbidden to build along the rear of the house without leaving any open space for maintaining natural ventilation inside the unit to avoid thermal problem. Interviewees noted that some modifications, particularly to the rear of the unit, resulted in uncomfortable and potentially unhealthy indoor thermal conditions. However, this recommendation, even if applied to future RIT housing, could still lead to less than ideal conditions if there is no assistance received from, or offered by, an expert during the 
transformation process.

\section{ACKNOWLEDGEMENT}

We thank Universitas Sebelas Maret for funding this research under the Maintenance Research Group Research Scheme based on contract number 632/UN27.21/LT/2016.

\section{REFERENCES}

Aryani, S.M., Mulyadi, Wahyuningsih, I.E.S., 2015. The House Design Transformation: The Preferences and the Patterns. The $5^{\text {th }}$ Sustainable Future for Human Security. Procedia Environmental Sciences, Volume 28, pp.717-724

Aryani, S.M., Sasongko, S., Wahyuningsih, I.E.S., 2016. The Design Transformation Evaluation of the Growing Initial Unit on National Public Housing (Evaluasi Transformasi Desain pada Program Ruang Rumah Inti Tumbuh PERUMNAS). Research Report, Universitas Sebelas Maret (in Bahasa)

Handoko, B., 1999. Modest House Transformation Pattern as Adaptive Behavior Pattern of the Occupants; Case Study on Griya Praja Mukti Housing Neighborhood Kendal Central Java (Pola Perubahan Rumah Sederhana sebagai Pola Perilaku Adaptasi Penghuni: Studi Kasus pada Kompleks Perumahan Sederjan Griya Praja Mukti Kabupaten Dati II Kendal Jawa Tengah). Master Thesis, Bandung Institute of Technology (in Bahasa)

Isnin, Z., Ramli, R., Hashim, A.E., Ali, I.M., 2012. Sustainable Issues in Low Cost Housing Alternation Projects. Procedia - Social and Behavioral Science, Volume 36, pp. 393-401

Manalang, R.T., Munemoto, J., Yoshida, T., Espina C., 2002. A Study on Residents' Self-Built Improvement at MRB Dwelling Inits in Metro Manila. Journal of Asian Architecture and Building Engineering, Volume 1(2), pp. 177-184

Menteri Permukiman dan Prasarana Wilayah Indonesia (Indonesia Ministry of Infrastructure), 2002. General Guideline for Health Modest House in Indonesia Ministry of Infrastructure on Technical Guideline for Building the Health Modest House (Pedoman Umum Rumah Sehat Sederhana dalam Keputusan Menteri Permukian dan Prasarana Wilayah Nomor: 403/KPTS/M/2002 Tentang Pedoman Teknis Pembangunan Rumah Sederhana Sehat (Rssehat)), pp. 1-17 (in Bahasa)

Natakun, B., O'Brien, D., 2009. Extending the House/ Extending the Dream: Modifications to Government-built Housing in Bangkok Metropolitan Region. Journal of Architectural Planning Research and Studies, Volume 6(3), pp. 47-64

Nurasrizal, 2010. Core House Development on Livable Housing for Poor Family in Kayu Gadang Village Sawahlunto City (Pertumbuhan Rumah Inti pada Perumahan Layak Huni bagi Keluarga Miskin di Dusun Kayu Gadang Kota Sawahlunto). Master Thesis, Diponegoro University (in Bahasa)

Rahadi, R.A., Wiryono, S.K., Koesrindartoto, D.P., Syamwil, I.B., 2012. Relationship between Consumer Preferences and Value Proportions: A Study of Residential Product. Procedia Social and Behavioral Science, Volume 50, pp. 865-874

Rahim, Z.A., Hashim, A.H., 2012. Adapting to Terrace Housing Living in Malaysia. Procedia - Social and Behavioral Science, Volume 36, pp. 47-157

Saputra, H.O., 2004. The Effect of Orientation Building on the Heat Decrease inside the House Unit in Wonorejo Public Housing Surakarta (Pengaruh Orientasi Bangunan terhadap Penurunan Panas pada Rumah Tinggal di Perumahan Wonorejo Surakarta). Master Thesis, Diponegoro University (in Bahasa)

Schneider, T., Till, J., 2005a. Flexible Housing: Opportunities and Limits. Architectural Research Quarterly, Volume 9(2), pp. 157-166 
Schneider, T., Till, J., 2005b. Flexible Housing: The Means to the End. Architectural Research Quarterly, Volume 9(3), pp. 287-296

Sjaifoel, E., 2008. Kajian Perubahan Fisik Rumah Tinggal pada Permukiman Martubung Medan. Master Tesis, Universitas Sumatera Utara (in Bahasa)

Sueca, N.P., 2004. House Transformation: the Prospect for Improving the House Condition in Indonesia; A Preliminary Study (Transformasi Rumah: Prospeknya untuk Memperbaiki Keadaan Rumah di Indonesia (Suatu Studi Pendahuluan)), Jurnal Permukiman Natah, Vol. 2 (1), pp. 10-16

Sugini, 1999. House Change Typo Morphology in the Minomartani Housing Yogyakarta (Tipomorfologi Perubahan Rumah pada Perumahan Minomartani Yogyakarta). Jurnal Logika, Volume 3(4), pp. 71-89 (in Bahasa)

Sugiyono, 2011. Quantitative, Qualitative and R\&D Research Method (Metode Penelitian Kuantitatif, Kualitatif dan R\&D). Bandung: Alfabeta (in Bahasa)

Yatmo, Y.A., Atmodiwirjo, P., 2013. Spatial Strategies for Domestic Service Activities in Urban Kampung Houses. International Journal of Technology, Volume 4(1), pp. 24-33

Zavei, S.J.A.P., Jusan, M.M., 2012. Exploring Housing Attributes Selection on Maslow's Hierarchy of Needs. Procedia - Social and Behavioral Science, Volume 42, pp. 311-319 